\title{
Factors affecting Retirement Security
}

\author{
Dr. Aref Aghaei Hervani
}

Instructor of Business Administration

School of Business Administration

University of South Carolina Aiken

United States

\author{
Dr. Paul Link Hudson \\ Dr. Marouen Ben-Jebara
}

Assistant Professor of Management

School of Business Administration

University of South Carolina Aiken

United States

\section{Dr. Sanela Porca}

Professor of Economics and International Business

School of Business Administration

University of South Carolina Aiken

United States

\begin{abstract}
This study explores the challenges facing the US population regarding financial security, particularly as it relates to retirement security. It extends the review of the literature regarding financial literacy education based on previous literature, investigating the role of financial literacy education as it relates to managing bills on time, budgeting techniques, and saving regularly, and investing in retirement accounts. Previous research on financial literacy knowledge is explored. Lack of knowledge may be a reason for not following recommended practices. Research shows that financial literacy knowledge may explain better cash-flow management, and savings and investment behaviors. The research focuses on a number of areas in which there is a disparity among White, Black, and Hispanics in the USA and it further investigates number of issues related to financial security related to minorities, including household income, savings and asset allocation issues, home ownership, pension plans, and retirement savings and retirement security issues. It presents recent information on a number of relevant financial variables that relate to minority retirement security.
\end{abstract}

Keyword: Financial literacy, retirement insecurity, retirement accounts, home-ownership, saving barriers, financial planning, pension plans.

\section{Introduction}

Retirement can be described as "the process that starts with planning and decision making some time before the actual end of one's working life". Preparation is one of the most critical factors influencing the creation of retirement income. Simply put, the more preparation that one puts in, the more satisfaction that is gained (Muratore \& Earl, 2010).Hewitt et al. (2010) define retirement as "the period following an individual's complete withdrawal from participation in the workforce".

Retirement planning is increasingly complex, though many themes and trends can be deduced (Olsen \& Whitman, 2007). Planning and making decisions for this time of life depend on a variety of factors such as pensions, savings, disability, satisfaction with employment, and attitudes (Orel et al., 2004). Pensions are incentives provided by employers to draw in and maintain employees. They are not required by employers but incentivize employment to draw in profitable and new employees. The benefits of a pension often outweigh the costs on a weekly or monthly scale (Casciari \& Borowski, 2013). According to the National Compensation Survey (NCS) in 2018, 69 percent of workers in the United States had access to a retirement program through their employers. Access to a defined benefit retirement plan was given to 27 percent of workers, yet only 23 percent of them participated in the defined benefit retirement plan. Similarly, 58 percent of the U.S. workers had access to a defined contribution retirement plan, but only 40 percent of these workers participated in the plan. 
Despite numerous pensions plans and retirement options available during the active working life, many retirees experience financial and economic difficulties during retirement time. Numerous reports are confirming the disparities in retirement wealth among Americans. For example, minorities, specifically Blacks and Hispanics, are significantly worse off than their counterparts. Therefore, in order to improve the quality of life for all seniors, the federal and state governments have created various services and programs that are available for aging adults.

In conjunction with state resources, federal funds are allocated to provide seniors and their caregivers with muchneeded assistance. Federal and state governments have been vital in providing resources for many impoverished senior adults and allowing them to maintain an adequate living standard. This paper examines the factors that affect retirement security in general, with a special focus on retirement security challenges faced by minorities in the United States. An extensive literature review on the subject of retirement and retirement security issues is provided as well as the recommendation for improvement of the wellbeing of the future retirees. More specifically, the authors recommend that the solution to retirement (in)security is the worker's financial literacy. Furthermore, some practical and effective means of improving retirement savings is the discouragement of opt-in retirement plans. Employers should automatically enroll employees in a savings plan. Educational programs most often improve retirement plan inclusion and are, therefore, an all-around benefiting action. When employees are not obligated to purchase retirement planning, they often do not. By employers taking the initiative and automatically enrolling them in, the employers are thereby making retirement a better time (Olsen \& Whitman, 2007).

\section{Literature Review on Retirement and Financial Security}

Economic literature examines various theoretical aspects of retirement security. For example, these range from structural theories which consist of the core industry, primary occupational sector, and female predominant occupations, to individual theories or human capital investment inclusive of educational level, training \& work experience, life course factors such as marital status, and health status and disability (Ferrie et al., 2004; James et al., 2016). All of these factors were used to determine the impact on retirees and pre-retirement, especially for low income and minority communities. In order to better understand financial decisions from the perspective of gender differences, different analytic frameworks suggest that factors such as standard life cycle, household bargaining framework, and men's and women's behavioral attitudes play important role in retirement security (Hui et al., 2011). In order to estimate retirement stability, these theories and perspectives define the dependent variable as an individual's pension plan(s): defined-benefit, defined-contribution, individual retirement plans. On the other hand, the independent variables used in these studies include indicators such as marital status, wealth accumulation, savings, financial education or literacy, gender, race, ethnicity, employment, marital status, age, living parents and/or grandparents, wealth, education and financial education.

One of the earliest studies on financial literacy in the United States was a national survey conducted by Cutler (1997). The findings of this study suggest that the American public is not well informed about financial matters, in particular, insurance, health care, and social security. Similarly, subsequent studies suggest that most financial planning among individuals and families takes place as a result of trial and error. The main findings of this body of work suggest that well-informed, financially educated consumers should make better retirement decisions. As of 2013, the majority of households did not prepare a detailed household budget (Jacobe, 2013). Research has shown evidence that budgeting may be the low end of the behavioral hierarchy (Jing Jian Xiao \& O'Neill, 2018). Out of a survey of 20 positive personal financial practices, O'Neill et al. (2017) found that budgeting was one of the five least frequently performed activities. The individuals who followed a budget guidance scored higher on both financial practice and health indices.

Financial education should begin with simple financial management practices such as paying bills on time, making written budgets, and regularly comparing actual expenditures to planned expenditures (O'Neill, 2002). There is evidence that many families use short-term budgets and prefer techniques that require little energy (Davis \& Carr, 1992; Muske \& Winter, 1999, 2001). There is also evidence that families with various income levels have trouble resisting spending temptations (Beverly et al., 2003).

One of the most common financial management principles is to save regularly, generally by setting aside some amount of savings before paying for expenses (O'Neill, 2002). Schreiner et al. (2002) conclude that financial education was found to be positively associated with the amount of average monthly net deposits. Many households have very low levels of wealth. Numerous studies show that more than half of U.S. households do not have adequate emergency funds (West \&Mottola, 2016; Chang et al., 1997; Haveman \& Wolff, 2005; Wolff, 2000). Bernheim (1998) suggests that Americans are saving too little for retirement. There is also a substantial body of research and policy initiatives targeted at helping low-income families accumulate assets through Individual Development Accounts (Feldman, 2018;Oliver et al., 2006; Schreiner et al., 2002) and homeownership programs (Wainer \& Zabel, 2020). Bernheim and Garrett (1996) also present results showing that workplace financial education is an important factor for the total savings rate, but not total wealth. 
Lack of knowledge about the principles of financial management and financial matters could explain why some families do not follow recommended financial practices. In fact, research shows that youth and adults in the United States have disturbingly low levels of economic, financial, and consumer literacy (Kotlikoff \& Bernheim, 2001). Aizcorbe et al. (2003) conclude that the percentage of unbanked families was much higher for low-income, younger, non-White, or Hispanic families. Two common indicators that families are overburdened by debt are a ratio of debt payment to income greater than $40 \%$ and being substantially late with credit card payments.

These percentages were higher for lower-income families (Aizcorbe et al., 2003). The idea that financial education improves retirement savings relies on the assumption that employers tend to introduce workplace financial education in remedial circumstances (Clark \& Schieber, 1998).

Furthermore, there has been a great deal of research on the issue of financial education, either from a policy perspective (Bayer et al., 2009; Bernheim, 1998; Braunstein \& Welch, 2002; Caskey, 2001; Fox et al., 2005) or a pragmatic perspective (Bowen, 1996; Garman, 1998; Hogarth \& Swanson, 1993; Montalto, 2002; Perry \& Ards, 2001; Toussaint-Comeau \& Rhine, 2000) Although few research studies show the correlation between the level of financial education and financial management behaviors. Bernheim et al. (2001) showed that consumers who graduated from states with mandated financial education were more likely to have higher savings rates and higher net worth. Hogarth and Hilgert (2002) showed that the higher a consumer's financial knowledge (based on a quiz score), the higher the probability that the consumer undertook more positive financial management behaviors and used more financial products and services. The bottom line is that knowledge and learning preferences seem to be associated with more effective financial behaviors. More knowledgeable persons were more likely to engage in more cash-flow management, saving, and investment behaviors (Hilgert et al., 2003). Similarly, financial knowledge can be statistically linked to financial practices related to credit as well as the cash-flow management, saving, and investing behaviors cited above.

\section{Retirement Security Issues Facing Minorities}

According to the retirement literature, Blacks, women, and Latinos have significantly lower financial capability than their counterparts (Danigelis \& McIntosh, 2001; Dietz et al., 2003; Glass \& Kilpatrick, 1998; Lusardi, 2008; Lusardi \& Mitchell, 2011; Lusardi \& Mitchelli, 2007). Brown, (2012), Kochhar et al., (2011), Kaba, (2011), Angel et al., (2014), and Tamborini and Purcell, (2016) present a growing retirement income gap between households of color and white households from 1989 to 2001. In 1989, white households had an expected retirement income of $\$ 59,100$, on average, compared to $\$ 22,200$ for Blacks and Latinos. By 2001, the expected retirement income for white households climbed to $\$ 80,800$ as opposed to $\$ 28,100$ for households of color. This growing gap was attributed to the shift from defined benefits to defined contributions."

Furthermore, research shows that on average Hispanics have lower levels of educational attainment, and therefore less earning power, and a lower level of savings than non-Hispanics. According to this body of literature, on average, Hispanics are also less likely to have an access to an employer-sponsored retirement plan. Coupled with the findings that many Hispanics and Blacks are less likely to use formal financial advice, it is not surprising that all of these factors produced a significant gap in financial literacy, which in return have important implications for individual savings, investing, and retirement planning (Olsen \& Whitman, 2007, 2011).

Naturally, on average, lower-paying jobs of minorities produce lower social security payouts relative to the social security payouts for Whites (Hendley \& Bilimoria, 1999). With a specific focus on minority women, studies suggest fewer opportunities for insurance coverage, which places them in disadvantages throughout life. Similarly, some Hispanic and Black women do not receive full social security benefits due to a lack of contributions throughout life. Angel et al., 2007 suggest that the decreasing rate of marriage for Hispanic and Black women makes them less eligible for additional social security.

When it comes down to a labor force participation trend, non-Hispanic Whites often claim a full 35 years' worth of workforce earnings. On the other hand, minorities often received less than the full 35 years' worth of workforce earning due to the shorter life expectancies for minorities (Hendley \& Bilimoria, 1999). All of this means that there are many Americans who currently do not have enough income for retirement (Miller et al., 2015).

\section{Factors Affecting Financial Security}

This section examines factors that influence an individual's retirement security. These variables include savings and asset allocation, home ownership, retirement account savings, participation and access to employment dazed retirement plans, household income, and pension plans among others.

\section{Savings and Asset allocation}

Whitaker et al. (2011) investigated the determinants of an individual's saving activities. More specifically, Whitaker et al.(2011), Holden and Schrass (2019),and Engelhardt \& Kumar (2007) postulated that savings plans depended on the type of job, type of employer, the number of adults and/or children in the household, the worker's 
education level and attitude relative to the family financial condition and possibly any unexpected inheritance. Other studies aimed at identifying the policies and programs that affect the gender differences in retirement saving decisions, specifically, how economic empowerment of married and cohabiting women changes the outcome of a households' financial decision-making and to identify if women would be prepared for retirement.

Mauldin et al. (2013) examined low-income individuals' propensity to save. Not surprisingly, they determined that the low rate of saving among low-income individuals is due to the low-income level and high expenditures. Not surprisingly, Browning and Lusardi (1996) found that as income increased, there is a steady increase in propensity to save. Low-income households who reported owning a bank account were significantly more likely to save. On the other hand, households that receive welfare were less likely to save. Another approach was taken by Jing J Xiao (1996). Xiao divided household income into earned and unearned income and found that unearned income showed negative effects on the savings accounts, savings bonds, and cash value life insurance. On the other hand, earned income had positive effects on ownership of the majority of financial assets. Riley $\mathrm{Jr}$ and Chow (1992)showed that relative risk aversion decreases as one rises above the poverty level and decreases significantly for the very wealthy. The wealthier households choose more to invest a large portion of their wealth in risky assets than less wealthy households. In addition, the wealthier retirees have more diverse portfolios of financial assets and own more stocks, mutual funds, cash value life insurance, and other financial assets. On the other hand low networth households tend to predominantly own cash and cash equivalent financial assets (Iglesias et al., 2004).

The purpose of the current study is to summarize the existing literature on retirement trends and financial security with a special focus on the net worth by race and during the period between 2009 and 2019 (Figure 1). The data presented shows that an average white American has fourteen times higher net worth than the average African American. With respect to average Hispanic America, their net worth is five times less than the average white Americans. White Americans have experienced the highest compounded aggregate net worth growth rate (CAGR) between 2009 and 2017 (almost 18.92\%) followed by the Hispanics (9.28\%) and finally Blacks (5.19\%).

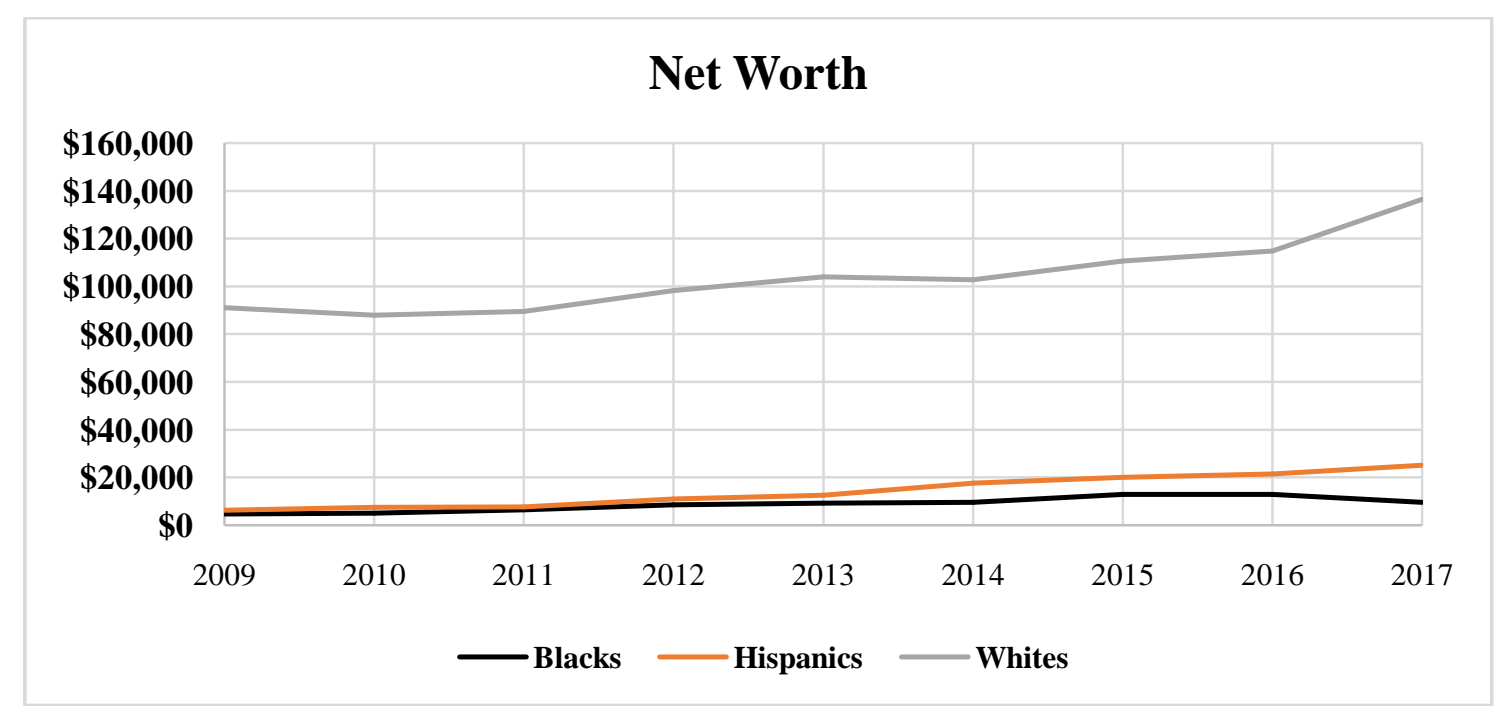

Figure 1: Net Worth Evolution

\section{Home ownership}

Homeownership is a major wealth-building technique for families as most of them derive an important part of their net worth from their homes. Homeownership rates rise with a rise in real income. Over time, an increase in real income will contribute to the raise of the aggregate homeownership rate. Lyons et al., 2003 found several reasons why home ownership is lower among low-income households. Factors such as financial risks of homeownership, few tax advantages, and the high transaction cost of buying and selling homes contribute to the low homeownership among low-income households. Once when homeownership is established, most of the wealth held by low-income households is wrapped up in their house. Housing wealth is their only real asset (Lucey, 2005). As a result, lowincome homeowners are generally wealthier than low-income renters. This shows that homeownership can be an effective asset-building strategy for low-income households.

Although mortgage interest rates have declined over time, purchasing a home is still out of reach for many lowincome households. The insufficient funds for the down payment and for closing costs are the main reasons for this trend. Herbert et al., (2012) concludes that in addition to the high borrowing costs, low-income households often have low credit scores and thus are perceived as the high-risk borrowers. 
Home ownership plays a significant role in wealth growth for retirement (Lersch and Dewilde, 2018). Families who rent, rather than own, are less likely to have an advantage in saving for their futures. Additionally, family inheritance accounts for the ability to purchase a home, which aligns with money for retirement.

For example, Caucasian families who can provide money to relatives for down payments on homes are able to gain equity eight years faster than African Americans who do not have relatives to assist them with the down payments. Figure 2 indicates that not only Whites' homer value is higher than the other two groups, it also is increasing at a higher rate.

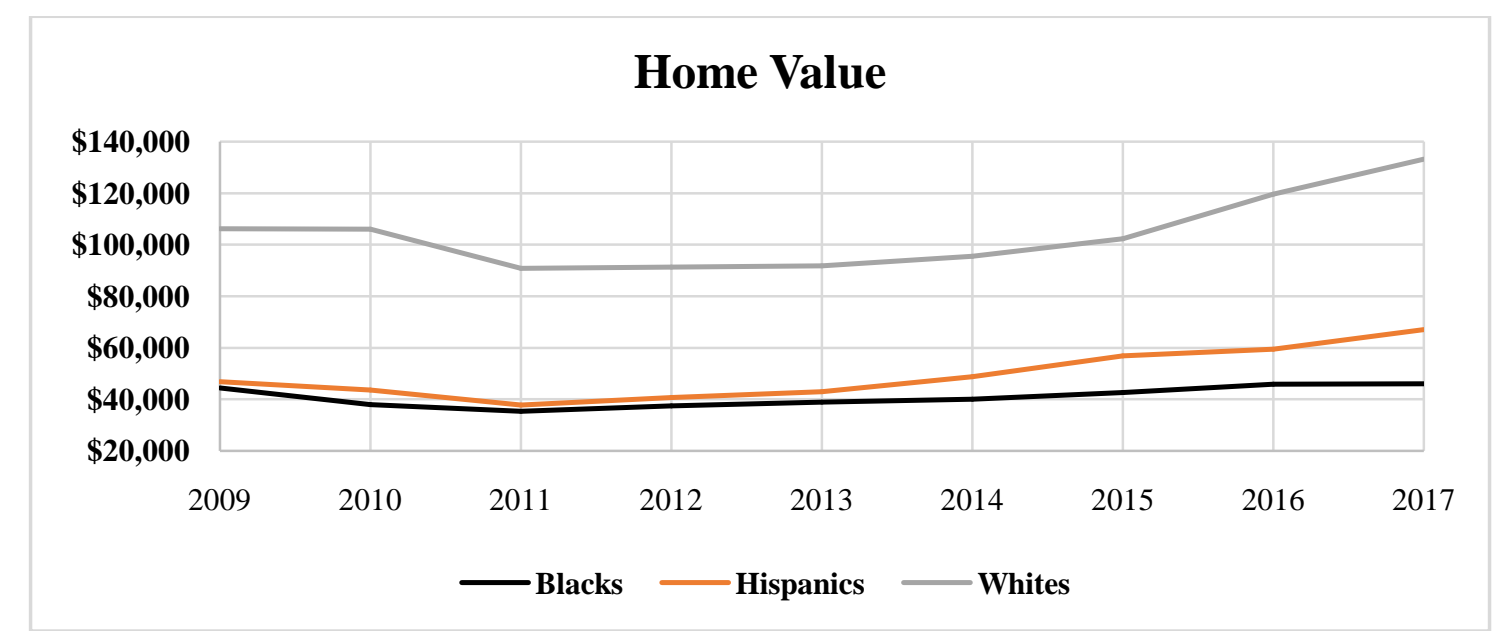

Figure 2: Home Value Evolution (2009-2017)

\section{Retirement Account Savings}

Traditionally, financial support for retirement for most individuals comes from the following sources: Social Security, Pensions, and/or Personal Savings. Personal savings for retirement can take the form of Individual Retirement Accounts (IRAs) and Annuities. The IRA is an account set up at a financial institution that allows an individual to save for retirement on a tax-deferred basis. The IRA was created by the Employee Retirement Income Security Act in 1974 and has grown to account for about $25.4 \%$ of the U.S. retirement wealth, and $8.5 \%$ of total U.S. household financial assets at the end of the year 2008 (Hira \& Loibl, 2005). IRAs are especially important for workers whose employer does not offer employer-sponsored plans like the 401(k).

The majority of minorities rely on their retirement income from programs such as Social Security (Gassoumis et al., 2011; Gibson \& Burns, 1991). Gassoumis et al. (2011) articulate that across all racial and ethnic groups over 65, 90\% percent of White, $84 \%$ percent of African Americans, $77 \%$ of Latino, and $67 \%$ of Asians rely on Social Security as the main source of income. Their research indicates that all racial and ethnic groups that fall below $200 \%$ of the poverty line have an over-reliance on Social Security. Many individuals fail to consider their retirement financial well-being during their labor force participation for various reasons. This leads to personal savings being the weakest resource during their retirement. The majority of retirees depend on Social Security Benefits as the main financial resource in retirement. Figure 3 highlights the evolution of retirement savings between 2009 and 2017.

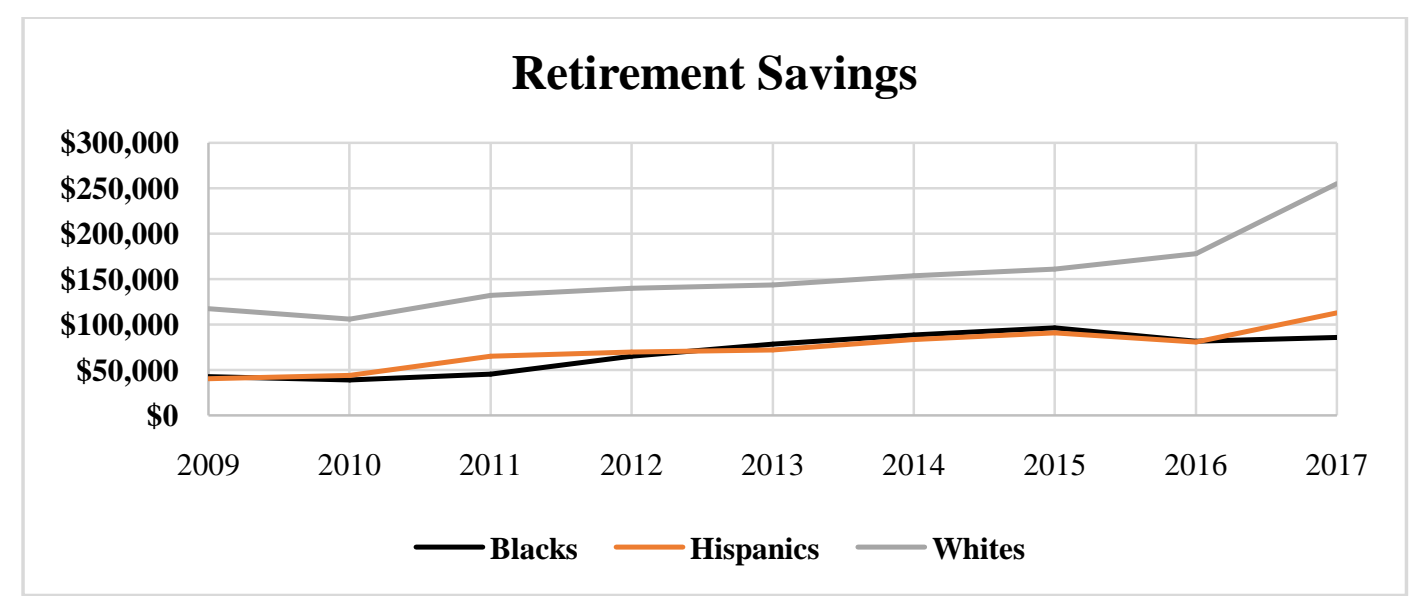

Figure 3: Retirement Savings Evolution (2009-2017) 


\section{Participation and Access to Employment-Based Retirement Plans}

Numerous studies have shown that pension plan participation has positively related to retirement security (Hewitt et al., 2010; Kim et al., 2005; Olsen \& Whitman, 2007).

Several studies have also shown that minorities, in general, save less since a low percentage of them participate in their employer's 401(k) plans (Kabir and Shari, 2018). Regardless of race, currently more than 57 million people in the United States do not have an employer-provided savings program. According to the statistics collected by the American Association of Retired Persons (AARP), 94 percent of workers who do not have access to retirement savings plans at work end up facing their retirement with less than $\$ 25,000$ in total savings and investments.

Traditionally, one of the main retirement saving approaches is through an employer pension plan. Usually, the employer places funds into a savings or an investment account on behalf of the employee and as an incentive for long-term employees. Other alternative forms of planning for retirement includes individual retirement account (IRA), Roth IRA account, 401 (K) account, and Social Security, among others.

The difference between a defined contribution plan and a defined benefit plan is that employees are not required to contribute any of their paychecks to participate in a defined benefit plan. It is fully sponsored by the employer. However, with a defined-contribution plan, such as a 401(k) or 403(b) plan employees are required to contribute a portion of their earnings and the plan's success is related to the success of the stock market. Herd (2009) emphasizes that "the employer-provided pension now places the risks the risk on the individual just as personal savings does". This higher individual contribution and higher risk are problematic for women and minorities. Weller (2007) concludes that retirement wealth inequality rose with the proliferation of Defined Contribution plans.

Social Security is the most effective way of assuring at least a small nest egg for retirement for most American households, regardless of race, for three main reasons. First, unlike pensions, Social Security is for the most part universal. Second, it influences saving, which is otherwise very hard for low-income households, among which minorities are overrepresented. And, third, its benefit structure is progressive, replacing a higher percentage of the pre-retirement wages of low earners than of higher earners. Unlike the current regressive system of tax deferrals for private savings through IRAs, 401(k)s, and other private accounts, Social Security acts as an equalizer for the regressive nature of private savings.

Social Security is considered the most reliable source of income for minorities during retirement. Herd (2009)surmises that overall retirement savings are moving from a collective approach to a more individualized one. The author proposes that the traditional three-legged stool of retirement, namely social security, personal savings, and employer-provided pensions has shifted to a two-legged stool as a result of recent economic fluctuations. Previously the personal-savings leg was thought to have the most risk for the individual while Social Security and employer-provided pensions had more collective risk. However, Social Security Benefits are meant to be a supplemental source of income. In fact, it is intended to be one of three methods of accumulating wealth to support individuals in retirement. The other two sources of retirement income are personal savings accounts and employerprovided pensions. Retirement income has been viewed as a three-legged stool, each leg supporting a balanced retirement income (Collins \& Yeskel, 2011; Collins et al., 2005). In the past, "the Social Security leg and the employer-pension leg pooled risk across all beneficiaries, with the government and employers, respectively, assuming responsibility. The personal-savings leg posed the most risk to the individual, but it represented only a third of the structure (Herd, 2009). Collins and Yeskel (2011) articulate that "as personal savings plummet and fewer and fewer workers have pension funds, the prospects for a large percentage of people retiring into poverty grows. As a result, some minorities that meet the age requirements for retirement are unable to do so. In fact, they may decide to continue working to provide additional financial support for themselves.

Individuals who plan for their retirement, attend financial workshops and receive advice, and have more confidence in social security and Medicare tend to have more saving in their bank account, more household income and are healthier than an individual that had not any plans for retirement and their needs (Kim et al., 2005). Olsen and Whitman (2007) conclude that educational programs most often improve retirement plan inclusion and therefore, employers should automatically enroll employees in a saving plan. Hewitt et al. (2010) found a positive relationship between planning for retirement and satisfaction with the results of that planning. Simply put, those who plan early are generally more satisfied with the retirement life.

\section{Household income}

It should not be surprising that numerous studies have shown that individuals with higher income had more positive retirement confidence (e.g., Angel et al., 2007; Kim et al., 2005). Kim et al. (2005) found that those with annual incomes over $\$ 75,000$ have better attitudes regarding retirement compared to those with $\$ 25,000$. Additionally, studies have shown that minority workers have lower retirement confidence and less retirement preparation primarily due to lower-income. Low-income earners generally tend to lack financial literacy. As a result, those individuals do not manage their money efficiently and are generally not familiar with all the investment 6 
opportunities. Most low-income individuals have inadequate knowledge of the employer-based retirement plan, they either do not know that it is being offered or do not realize its importance, therefore they tend not to participate. Figure 4 shows the evolution of median income by race.

While there is an increase in the median income across Whites, Blacks, and Hispanics, we can observe a large discrepancy and differences across the three groups.

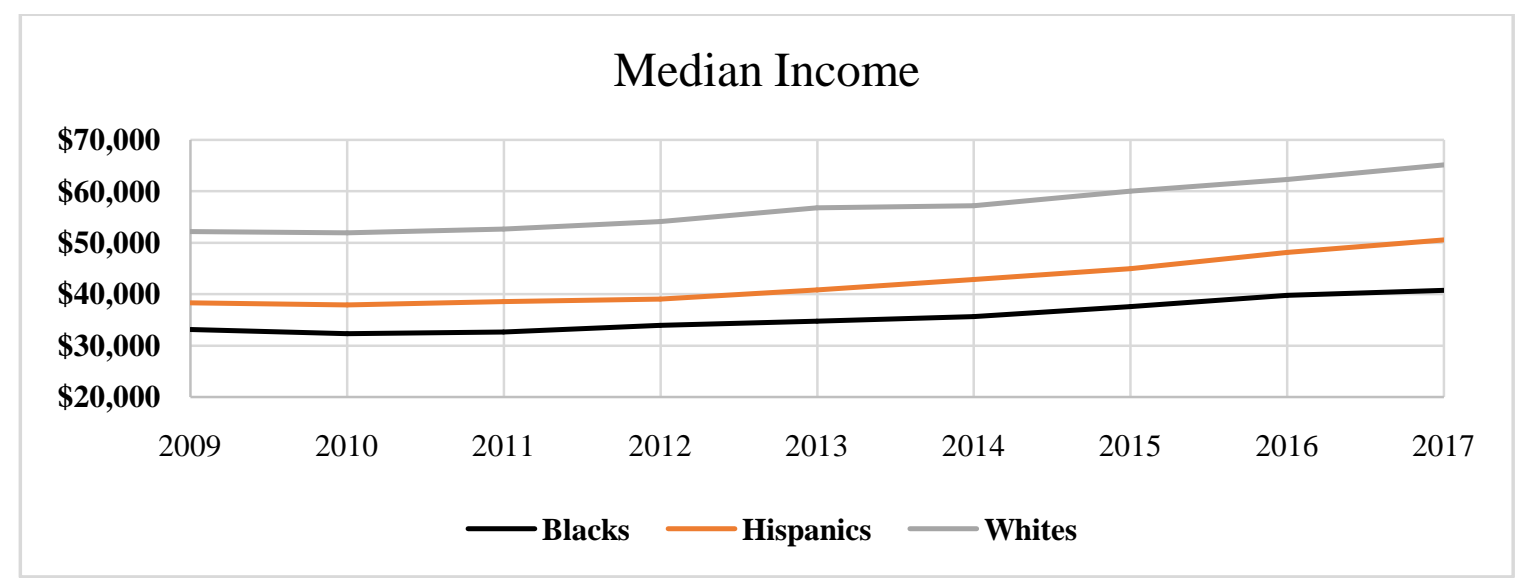

Figure 4: Median Income Evolution (2009-2017)

The difference between a defined contribution plan and a defined benefit plan is that employees are not required to contribute any of their paychecks to participate in a defined benefit plan. It is fully sponsored by the employer. However, with a defined-contribution plan, such as a 401(k) or 403(b) plan employees are required to contribute a portion of their earnings and the plan's success is related to the success of the stock market. Herd (2009) emphasizes that "the employer-provided pension now places the risks the risk on the individual just as personal savings does". This higher individual contribution and higher risk are problematic for women and minorities. Weller (2007) concludes that retirement wealth inequality rose with the proliferation of Defined Contribution plans.

Social Security is the most effective way of assuring at least a small nest egg for retirement for most American households, regardless of race, for three main reasons. First, unlike pensions, Social Security is for the most part universal. Second, it influences saving, which is otherwise very hard for low-income households, among which minorities are overrepresented. And, third, its benefit structure is progressive, replacing a higher percentage of the pre-retirement wages of low earners than of higher earners. Unlike the current regressive system of tax deferrals for private savings through IRAs, 401(k)s, and other private accounts, Social Security acts as an equalizer for the regressive nature of private savings.

Social Security is considered the most reliable source of income for minorities during retirement. Herd (2009)surmises that overall retirement savings are moving from a collective approach to a more individualized one. The author proposes that the traditional three-legged stool of retirement, namely social security, personal savings, and employer-provided pensions has shifted to a two-legged stool as a result of recent economic fluctuations. Previously the personal-savings leg was thought to have the most risk for the individual while Social Security and employer-provided pensions had more collective risk. However, Social Security Benefits are meant to be a supplemental source of income. In fact, it is intended to be one of three methods of accumulating wealth to support individuals in retirement. The other two sources of retirement income are personal savings accounts and employerprovided pensions. Retirement income has been viewed as a three-legged stool, each leg supporting a balanced retirement income (Collins \& Yeskel, 2011; Collins et al., 2005). In the past, "the Social Security leg and the employer-pension leg pooled risk across all beneficiaries, with the government and employers, respectively, assuming responsibility. The personal-savings leg posed the most risk to the individual, but it represented only a third of the structure (Herd, 2009). Collins and Yeskel (2011) articulate that "as personal savings plummet and fewer and fewer workers have pension funds, the prospects for a large percentage of people retiring into poverty grows. As a result, some minorities that meet the age requirements for retirement are unable to do so. In fact, they may decide to continue working to provide additional financial support for themselves.

\section{Conclusion}

The decision of when to retire is also influential in determining an individual's financial security during retirement. Retiring early has a direct impact on the amount of Social Security Benefits received and this decision is based on certain behavioral and psychological aspects. Currently, many American workers do not understand their coverage and participation in retirement plans. If we add to this the workers' lack of understanding of how to calculate 
"time value of money," we can see how confusing saving for retirement can get. Because of all this, we are witnessing a high percentage of workers moving in and out of coverage, or simply not participating. Consequently, the Nation faces a real problem of retirement security for current and future retirees. Unfortunately, poverty is a serious issue facing retired Americans.

Very often the individuals decide to retire early mainly because of dissatisfaction with their job or being tired of working even though postponing retirement until full retirement age brings more financial security by increasing the social security benefit amount (Knoll, 2011). Those with more education on financial security and retirement generally have more savings in retirement accounts and more financial assets than their financiallyless-educated counterparts. Individual retirement income increases the standard of living for the elderly and decreases the reliance on other government programs like Medicaid.

The historical context of minorities in the workforce aligns with low retirement accumulation. Pension wealth is an important source of overall wealth, particularly for households nearing retirement. About $79 \%$ of white households have pension wealth, compared with $66 \%$ of black and $46 \%$ of Hispanic households (Choudhury, 2002). Consequently, they are unable to save for their respective retirements and less able to retire because of their lack of pension income and adequate savings. Marital status and the condition of one's health also play key factors in retirement savings for minorities. Unmarried minority men are less likely to be employed than married individuals, and more likely to exhibit higher levels of inactivity in the workforce (Hudson, 2002).

In conclusion, the common form of retirement in the U.S. includes three financial sources, social security, employee-pension plans, and individual savings. There is a strong dependence on social security in low-income households regardless of race.

For many Americans Social Security accounts for a substantial amount of retirement income. Low-income individuals directly depend on Social Security. There is evidence that increasing the retirement age will lessen the social security replacement rates (Butrica et al., 2012; Reno \& Lavery, 2007). When compared to poverty levels, social security does not necessarily provide enough to be at or above national guidelines for poverty. Therefore, a serious approach to the retirement preparation must be taken by all parties involved, workers, businesses, and government. Preparing for retirement is a very serious task that the current and future workers have to be aware of. If not educated about the costs of retirement and if not provided with an option of employer-sponsored retirement plans, future retirees will encounter many economic challenges after retirement. This will put an additional burden on government agencies. In order to ensure a comfortable retirement for all Americans, we need to start educating our current workers and business about retirement. Financial literacy is essential to one's economic prosperity and an adequate living standard.

\section{Reference List}

Aizcorbe, A. M., Kennickell, A. B., \& Moore, K. B. (2003). Recent changes in US family finances: Evidence from the 1998 and 2001 Survey of Consumer Finances. Federal Reserve. Bulletin, 89, 1.

Angel, J. L., Jimenez, M. A., \& Angel, R. J. (2007). The economic consequences of widowhood for older minority women. The Gerontologist, 47(2), 224-234.

Angel, Jacqueline L., Prickett, Kate C., and Angel, Ronald J., (2014), "Retirement Security for Black, Non-Hispanic White, and Mexican-Origin Women: The Changing Roles of Marriage and Work",Journal of Women, Politics \& Policy,35:3,222-241.

Bayer, P. J., Bernheim, B. D., \& Scholz, J. K. (2009). The effects of financial education in the workplace: Evidence from a survey of employers. Economic Inquiry, 47(4), 605-624.

Bernheim, D. (1998). Financial illiteracy, education and retirement saving. In O. Mitchell \& S. Schieber (Eds.), Living with defined contribution pensions (pp. 38-68). Philadelphia: University of Pennsylvania.

Bernheim, D., \& Garrett, D. (1996). The determinants and consequences of financial education in the workplace: Evidence from a survey of households (0898-2937).

Bernheim, D., Garrett, D. M., \& Maki, D. M. (2001). Education and saving:: The long-term effects of high school financial curriculum mandates. Journal of public Economics, 80(3), 435-465.

Beverly, S. G., Romich, J. L., \& Tescher, J. (2003). Linking Tax Refunds and Low-Cost Bank Accounts: A Social Development Strategy for Low-Income Families? Unpublished Research. Washington University in St. Louis.

Bowen, C. F. (1996). Informal money management education: Perceptions of teens and parents. Consumer Interests Annual, 42, 233.

Braunstein, S., \& Welch, C. (2002). Financial literacy: An overview of practice, research, and policy. Federal Reserve Bulletin., 88, 445.

Brown, T. (2012), "The Intersection and Accumulation of Racial and Gender Inequality: Black Women's Wealth Trajectories". Rev Black Polit Econ39, 239-258 (2012). https://doi.org/10.1007/s12114-011-9100-8 
Rowning, M., \& Lusardi, A. (1996). Household saving: micro facts and micro theories. Journal of Economic Literature, 34(4), 1797-1855.

Butrica, B. A., Smith, K. E., \& Iams, H. M. (2012). This is not your parents' retirement: comparing retirement income across generations. Social Security Buliten., 72, 37.

Casciari, M., \& Borowski, B. (2013). Rightsizing Public Employee Retirement Benefits: How Have the State Courts Resolved the Constitutional Issues? Benefits Law Journal, 26(1), 22.

Caskey, J. P. (2001). Can lower income households increase savings with financial-management education. Cascade: A community development publication of the federal reserve bank of Philadelphia, 46.

Chang, Y. R., Hanna, S. D., \& Fan, J. X. (1997). Emergency fund levels: Is household behavior rational? Financial Counseling and Planning.

Choudhury, S. (2002). Racial and ethnic differences in wealth holdings and portfolio choices: Social Security Administration, Office of Research, Evaluation, and Statistics.

Clark, R. L., \& Schieber, S. J. (1998). Factors Affecting Participation. In O. Mitchell \& S. Schieber (Eds.), Living with defined contribution pensions. Philadephia: University of Pennsylvania Press.

Collins, C., \& Yeskel, F. (2011). Economic apartheid in America: A primer on economic inequality \& insecurity. New York: The New Press.

Collins, C., Yeskel, F., \& Scholr, J. (2005). Economic Apartheid In America. New York: The New Press.

Danigelis, N. L., \& McIntosh, B. R. (2001). Gender's effect on the relationships linking older Americans' resources and financial satisfaction. Research on Aging, 23(4), 410-428.

Davis, E. P., \& Carr, R. (1992). Budgeting practices over the life cycle. Financial Counseling and Planning, 3(1), 3-16.

Dietz, B. E., Carrozza, M., \& Ritchey, P. N. (2003). Does financial self-efficacy explain gender differences in retirement saving strategies? Journal of Women \& Aging, 15(4), 83-96.

Engelhardt, G. V., \& Kumar, A. (2007). Employer matching and 401 (k) saving: Evidence from the health and retirement study. Journal of public Economics, 91(10), 1920-1943.

Flippen, C., \& Tienda, M. (2002). Workers of color and pathways to retirement. Public Policy and Aging Report, 12(3), 3-8.

Fox, J., Bartholomae, S., \& Lee, J. (2005). Building the case for financial education. Journal of Consumer Affairs, 39(1), 195-214.

Garman, E. T. (1998). Consumer educators, now is the time for a paradigm shift toward employee financial education. Consumer Interest Annual, 14, 48-53.

Gassoumis, Z. D., Lincoln, K. D., \& Vega, W. A. (2011). How low-income minorities get by in retirement: Poverty levels and income sources. Los Angeles, CA: USC Edward R. Roybal Institute on Aging.

Gibson, R. C., \& Burns, C. J. (1991). The health, labor force, and retirement experiences of aging minorities. Generations: Journal of the American Society on Aging, 15(4), 31-35.

Glass, C. J., \& Kilpatrick, B. B. (1998). Financial planning for retirement: An imperative for baby boomer women. Educational Gerontology: An International Quarterly, 24(6), 595-617.

Haveman, R., \& Wolff, E. N. (2005). Who are the asset poor? Levels, trends, and composition, 1983-1998. Inclusion in the American dream: Assets, poverty, and public policy, 61-86.

Hendley, A. A., \& Bilimoria, N. F. (1999). Minorities and social security: An analysis of ethnic differences in the current program. Social Security Bulletin, 62, 59.

Herbert, C. E., Belsky, E. S., \& Apgar, W. C. (2012). Critical Housing Finance Challenges for Policy Makers. Retrieved from https://www.jchs.harvard.edu/sites/default/files/w12-2_herbert_belsky_apgar.pdf

Herd, P. (2009). The two-legged stool: The reconfiguration of risk in retirement income security. Generations, 33(3), 12-18.

Hewitt, A., Howie, L., \& Feldman, S. (2010). Retirement: What will you do? A narrative inquiry of occupation- based planning for retirement: Implications for practice. Australian Occupational Therapy Journal, 57(1), 8-16.

Hilgert, M. A., Hogarth, J. M., \& Beverly, S. G. (2003). Household financial management: The connection between knowledge and behavior. Federal Reserve Bulletin., 89, 309.

Hira, T. K., \& Loibl, C. (2005). Understanding the impact of employer- provided financial education on workplace satisfaction. Journal of Consumer Affairs, 39(1), 173-194.

Hogarth, J. M., \& Hilgert, M. A. (2002). Financial knowledge, experience and learning preferences: Preliminary results from a new survey on financial literacy. Consumer Interest Annual, 48(1), 1-7.

Hogarth, J. M., \& Swanson, J. A. (1993). Voices of experience: Limited resource families and financial management. Paper presented at the American Home Economics Association: Family Economics \& Management Conference Proceedings.

Holden, Sarah and Schrass, Daniel, The Role of IRAs in US Households' Saving for Retirement, 2019 (December 11, 2019). ICI Research Perspective, December 2019 // Vol. 25, No. 10 
Hyde, M; Ferrie, J; Higgs, P; Mein, G; Nazroo, J; (2004) The effects of pre-retirement factors and retirement route on circumstances in retirement: findings from the Whitehall II study. Ageing and Society (24), Article 2. $10.1017 / \mathrm{S} 0144686 \mathrm{X} 03001624$.

Hudson, R. (2002). People of color and the challenge of retirement security. Washington, DC: National Academy on an Aging Society.

Hui, S., Vincent, C., \& Woolley, F. (2011). Understanding gender differences in retirement saving decisions: Evidence from the Canadian Financial Capability Survey (CFCS). Paper presented at the CEA Meetings.

Iglesias, J.-R., Gonçalves, S., Abramson, G., \& Vega, J.-L. (2004). Correlation between risk aversion and wealth distribution. Physica A: Statistical Mechanics and its Applications, 342(1-2), 186-192.

Jacobe, D. (2013). One in three Americans prepare a detailed household budget. Gallup,(June 3),[available at http://www. gallup. com/poll/162872/one-three-americans-prepare-detailedhousehold-budget. aspx].

James, J. B., Matz-Costa, C., \& Smyer, M. A. (2016). Retirement security: It's not just about the money. American Psychologist, 71(4), 334-344. https://doi.org/10.1037/a0040220

Kaba, Amadu Jacky (2011), "Explaining the Causes of the Black-White Wealth Gap in the United States", Sociology Mind 2011. Vol.1, No.3, 138-143.

Kabir, Hassan, M. and Shari, Lawrence, "Retirement Savings of the Hip Generation: A Study of Retirement Preparation among Individuals in Their Fifties (2018)", Southwestern Economic Review, Forthcoming.

Kim, J., Kwon, J., \& Anderson, E. A. (2005). Factors related to retirement confidence: Retirement preparation and workplace financial education. Financial Counseling and Planning, 16(2), 77-89.

Knoll, M. A. (2011). Behavioral and psychological aspects of the retirement decision. Social Security Bulletin, 71, 15.

Kochhar R, Fry R, Taylor P., (2011). "Wealth gaps rise to record highs between Whites, Blacks and Hispanics. Pew Research Center, Washington D.C.; 2011. Accessed September 15, 2011,from http://pewsocialtrends.org/files/2011/07/SDT-Wealth-Report 7-26-11_FINAL.pdf

Kotlikoff, L. J., \& Bernheim, B. D. (2001). Household financial planning and financial literacy. In Essays on Saving, Bequests, Altruism, and Life-cycle Planning (pp. 427-478). Cambridge, MA: MIT Press.

Lersch, Philipp M. and Dewilde,Caroline, (2018) Homeownership, saving and financial wealth: a comparative and longitudinal analysis. Housing Studies 33:8, pages 1175-1206.

Lucey, T. A. (2005). Assessing the reliability and validity of the Jump $\$$ tart survey of financial literacy. Journal of Family and Economic Issues, 26(2), 283-294.

Lusardi, A. (2008). Financial literacy: an essential tool for informed consumer choice? (0898-2937).

Lusardi, A., \& Mitchell, O. S. (2011). Financial literacy and planning: Implications for retirement wellbeing (0898-2937).

Lusardi, A., \& Mitchelli, O. S. (2007). Financial literacy and retirement preparedness: Evidence and implications for financial education. Business economics, 42(1), 35-44.

Lyons, A. C., Hogarth, J., Schuchardt, J., Smith, T., \& Toussaint-Comeau, M. (2003). Evaluating outcomes of personal financial education. Consumer Interests Annual, 49, 1-3.

Mauldin, T., Bowen, C. F., \& Cheang, M. (2013). Perceived barriers to savings among low-to moderate-income households that do not save regularly. Journal of Extension, 51(5), 5RIB4.

Miller, K., Madland, D., \& Weller, C. E. (2015). The reality of the retirement crisis. Washington, DC: Center for American Progress.

Montalto, C. P. (2002). Wealth-Poor Households in the United States. Report to the Consumer Federation of America and National Credit Union Foundation. Columbus, OH: Consumer and Textile Sciences Department, The Ohio State University.

Muratore, A. M., \& Earl, J. K. (2010). Predicting retirement preparation through the design of a new measure. Australian Psychologist, 45(2), 98-111.

Muske, G., \& Winter, M. (1999). Cash flow management: A framework of daily family activities. Journal of Financial Counseling and Planning, 10(1), 2.

Muske, G., \& Winter, M. (2001). An in-depth look at family cash-flow management practices. Journal of Family and Economic Issues, 22(4), 353-372.

O'Neill, B. (2002). Twelve key components of financial wellness. Journal of Family and Consumer Sciences, 94(4), 53.

O'Neill, B., Xiao, J. J., \& Ensle, K. (2017). Positive health and financial practices: Does budgeting make a difference? Journal of Family \& Consumer Sciences, 109(2), 27-36.

Oliver, M. L., Shapiro, T. M., \& Shapiro, T. (2006). Black wealth, white wealth: A new perspective on racial inequality: Taylor \& Francis.

Olsen, A., \& Whitman, K. (2007). Effective retirement savings programs: Design features and financial education. Social Security Bulletin, 67, 53.

Olsen, A., \& Whitman, K. (2011). An overview of contemporary financial education initiatives aimed at minority populations. In Consumer knowledge and financial decisions (pp. 77-97): Springer. 
Orel, N. A., Ford, R. A., \& Brock, C. (2004). Women's financial planning for retirement: The impact of disruptive life events. Journal of Women \& Aging, 16(3-4), 39-53.

Perry, V. G., \& Ards, S. (2001). The Freddie Mac consumer credit initiative: How consumers learn about credit and implications for consumer education and policy.

Reno, V. P., \& Lavery, J. (2007). Social security and retirement income adequacy. Social Security Brief, 25, 1-12.

Riley Jr, W. B., \& Chow, K. V. (1992). Asset allocation and individual risk aversion. Financial Analysts Journal, 48(6), 32-37.

Schreiner, M., Clancy, M., \& Sherraden, M. (2002). Saving performance in the American dream demonstration. Center for Social Development. St. Louis: Washington University.

Tamborini, Christopher R., andPurcell, Patrick (2016), "Women's Household Preparation for Retirement at Young and Mid-Adulthood: Differences by Children and Marital Status",Journal of Family and Economic Issues $37: 2$, pages $226-241$.

Toussaint-Comeau, M., \& Rhine, S. L. (2000). Delivery of financial literacy programs: Federal Reserve Bank of Chicago.

Wainer, A., \& Zabel, J. (2020). Homeownership and wealth accumulation for low-income households. Journal of Housing Economics, 47, 101624.

Weller, C. E. (2007). PURE: A Proposal for More Retirement Income Security. Journal of aging \& social policy, 19(1), 21-38.

Wolff, E. N. (2000). Recent trends in wealth ownership, 1983-1998. Jerome Levy Economics Institute Working Paper(300).

Xiao, J. J. (1996). Effects of family income and life cycle stages on financial asset ownership. Journal of Financial Counseling and Planning, 7, 21.

Xiao, J. J., \& O'Neill, B. (2018). Mental accounting and behavioural hierarchy: Understanding consumer budgeting behaviour. International Journal of Consumer Studies, 42(4), 448-459. 